\title{
IS MODERNIZATION REALLY UNIQUE IN THE HISTORY OF HUMAN DEVELOPMENT (OR JUST ANOTHER APPROACH THAT WILL SELF-DESTRUCT)?
}

\section{David Lempert}

\begin{abstract}
A frequent and largely untested assumption in modern social science and development studies is the uniqueness of contemporary societies (termed 'modern' or 'post-modern') and processes ('modernization', 'globalization', or 'global capitalism') in a new era (the 'anthropocene'). The belief in this uniqueness is offered as a justification for avoiding comparative study of contemporary social evolution processes using the tools of social science. This lack of comparative (contemporary and historical) study combines with the transformation of disciplines in ways that have dismantled social science and substituted reliance on what are 'religious' assumptions. This article tests the concept of 'modernization' as a specific cultural strategy or a part of the 'deep structure' of contemporary industrialization and empire and its beliefs. The article challenges the mythologies of the uniqueness of the contemporary historical period and the ability of human societies today to completely reshape culture and the environment without still being subject to rules of predictive and comparative social science. While there may be certain unique aspects of contemporary industrialization, the current period of historical evolution does not appear to be free of rules and patterns of rise and fall (or selfdestructiveness) of similar historic imperial cultures.
\end{abstract}

Keywords: modernization, post-modernism, deep structure, collapse, imperialism, social change, imperialism, neo-imperialism.

\section{Introduction}

This article offers a way to challenge the deadening assumptions that paralyze social sciences and humanities today, in an effort to move scholarship forward in the study of social evolution and historical processes. At the heart of social science today is an ideological belief about the supposed uniqueness of contemporary societies (calling them 'modern' or 'post-modern' [Bell 1972]) and of processes ('modernization', 'globalization', or 'global capitalism') as well as of the time we live in (naming it as a unique era, the 'anthropocene'). Where disciplines previously allowed comparisons, disciplines have now detached themselves in ways that prevent studies across time (e.g., splitting 'four field' anthropology so as to detach study of contemporary societies - social and cultural anthropology - from historical studies of humans and primates - archaeology, physical anthropology, and linguistics; restricting 'development studies' to contemporary processes) and define themselves by methodologies that do not allow comparisons (e.g., reporting methodologies like ethnography, surveys, and case studies). If social

Journal of Globalization Studies, Vol. 10 No. 1, May 2019 27-43

DOI: 10.30884/jogs/2019.01.03 
scientists no longer conduct historical comparisons with past civilizations and human (or primate) cultures and no longer seek to predict the future of contemporary society because of an assumption that what exists is something so new and incomparable that social science is useless, all that remains is religious dogma and magic (Freire 1970).

The belief systems embedded in much of social science today work not only to eliminate comparisons but to replace predictive social science with particular ideologies like production engineering (what is currently called 'economics') (Lempert 2018c), social control through criminology and assimilation (what is currently called 'sociology') and promotion of marketing technologies and chemical lobotomy (what is currently called 'psychology'), along with creating shallow forms of 'identity' as people lose their cultures and become absorbed into nation states (what is currently called 'anthropology') (Duncan 2012). Even in applied social science like 'development studies', that specifically defines its role as trying to see where societies are evolving and offering the technology to promote that evolution, there is little vision or measurement and little more than cheerleading for contemporary globalization or paralysis in the face of it and of potential collapse (Lempert 2014b).

This article poses and seeks to answer two related questions to help spark an awakening of the disciplines:

1) Is 'modernity' really something new and incomparable (sui generis) or are there comparison cases in human history to predict and explain it? (This is a central question of this article for analysis.)

2) Given that 'modernity' does introduce new types of cultural organization at a different level of human organization and relationship with the environment, that could not have been studied before, can social science still be used (e.g., methods of thought experiment analyzing 'deep structures' of socio-cultural processes or direct comparisons with other societies with similar phenomena) on key social science questions (such as predicting whether contemporary societies are sustainable or will fall)? (This is a central question of this article for discussion and prediction.)

To answer these questions, this article uses one of the classic tools of social science (holistic anthropological modeling) that is currently being discarded to move debate forward. This modeling works to identify the 'deep structure' (the coherency of all of the different structures and functions of a culture in meeting its survival needs and demonstrating their consistency with an overall survival strategy) today and looks to see whether the structure today is potentially comparable to past societies. Among key aspects of such modeling and comparison are the sub-questions of whether contemporary cultures are just another variant of complex societies undergoing technological change and characterized by professional and class structures, and imperialism/colonialism/ internal colonialism (Lempert 2012).

This article also tests five different suggested (hypothetical) logics ('driving forces') of contemporary industrial societies that are said to be unique (never existing historically in any previous cultures or society and therefore making contemporary society incomparable to others). Almost all of them seem easy to debunk as a key explanatory factor. Each seems to just describe a variant of the historical phenomenon of empire 
with the introduction of new technologies that occur throughout the human record. The one possible exception may be the administrative bureaucracies (Durkheim 1893) that characterize the 'new industrial state' (Galbraith 1967).

\section{Background}

Many of the debates today in what were the social science disciplines but that are challenged by or being transformed into 'humanities' are really debates over religious beliefs rather than debates over scientific findings and methods. It is these religious views that underlie the discussion of 'modernization' and other labels as something incomparable, part of a divine trajectory of human development, and not subject to laws of social science. [A longer discussion of the history of the current debates is presented in the full version of this article on line.]

\section{Methodology}

An expanded version of methodology is presented in the full version of this article on line.

\section{Analysis and Results}

The five most commonly presented models of the driving force or 'deep structure' of modernization or globalization, suggested above, are analyzed in this section, one at a time, to determine whether they really are the driving forces that they are claimed to be and whether they are really unique to contemporary cultures. Almost all of them seem easy to debunk as key explanatory factors. Each seems to just describe a variant of the historical phenomenon of empire with the introduction of new technologies that occur throughout the human record. The differences that do exist may just be an artifact of the scale of contemporary global culture. The one exception may be the administrative bureaucracies (Durkheim 1964 [1893]) that characterize the 'new industrial state' (Galbraith 1967).

\section{Analysis of the Deep Structure of Technological Imperative ('Techno-Fetishism'):}

The argument: On its face, the argument that modernization is characterized by a 'technological imperative' for constant and destructive transformation and replacement seems to be a convincing one. It is deeply rooted in literary and academic observations for more than two centuries and goes by a number of names. It also seems to echo personal experiences of uprooting, mobility, and disorientation. Popular literature has described the experience as 'future shock' (Toffler 1970) and laments that 'The place you live is no longer there. The place you love is gone' (Pierson 2007). In looking at the world today, something one might call the 'disaster in the anthropocene', this goal of destroying what we know to create an imperative for replacement with new technologies might explain why contemporary globalization seems to love and gamble on the human future with climate change, genocide, nuclear war and other technological novelties. It is as if every time humans build a 'better bomb', there is an itch to try it out and to believe that some other technology will arise immediately to prevent its aftereffects or its spread from destroying humanity. 
One of the best presentations of the logic of this potential deep structure principle of globalization was presented by Marshall Berman some three decades ago (1982). Berman believed that the driving force of modern society is a techno religion or technofetishism, that he calls 'techno-pastoralism'. Rather than being driven by consumption, he believed that modern culture is driven by the creation of new technologies and the love for the power and destructiveness of those technologies. In his view, the logic of the culture is to create all of the conditions that promote new technology, including the destruction of all previous sustainable cultures in their environments, the elimination of nature and beauty, and the generation of insecurity and risk. The resulting damages can and must only be treated by rapid development of some new technology that assures continuous insecurity promoting the search for and acceptance of the next destructive technology. At the heart of this dynamic is a hatred for (or fear of) nature and the love of technological power that has the ability to destroy and transform it through everything - from nuclear bombs and power plants to synthetic environments and genetic engineering.

In Berman's words, 'The innate dynamism of the modern economy, and of the culture that grows from this economy, annihilates everything that it creates - physical environments, social institutions, metaphysical ideas, artistic visions, moral values - in order to create more, to go on endlessly creating the world anew' (Berman 1982: 288). Berman finds echoes of this theme in two centuries of modern literature in different cultures, including Goethe's Faust (1832) and earlier in Rousseau's Julie (1761) as well as in European folklore like the Jewish myth of the Golem. 'To be modern is to find ourselves in an environment that promises us adventure, power, joy, growth, transformation of ourselves and the world - and at the same time that threatens to destroy everything we have, everything we know, everything we are' (Berman 1982: 15). In Faust, Berman notes the essence of modern man and woman in contemporary society as 'the consummate wrecker and creator, the dark and deeply ambiguous figure that our age has come to call the developer' (Berman 1982: 63) with 'the drive to create a homogeneous environment, a totally modernized space, in which the look and feel of the old world have disappeared without a trace' (Ibid.: 68).

Berman also believed that contemporary philosophers promoted this theme as this new modern religion, including Nietzsche (1873) and the anarchist Bakunin, who described destruction as ‘a creative passion' (Bakunin 1992 [1869]). He considered contemporary political actors, including political theorists like Samuel Huntington (1968), as promoters of policies to 'create' new nation states through 'forced modernization' achieved 'by bombing their traditional world into rubble' (Berman 1982: 331), describing them 'behind their facades' as 'the most violently destructive ruling class in history' (Berman 1982: 100).

Anyone who lives in the Third World and works in 'development' as this author does, observes at high speed what seems to be this theory at work. Unless all of the cultural monuments and architecture that roots people in their environments can be commodified for sale to tourists and repackaged as something outside of their original intent, almost all are immediately targeted and destroyed not only by commerce but by 
the agents of 'development'. In Vientiane, Laos, where this author recently worked and sought to document rich heritage for protection of identities, the damage was visible on a daily basis at the hands of the leading global institutions of our era. The World Bank situated its new office on and destroyed the foundations of the king's royal pagoda of the ancient capital city, Luxembourg Development paved the way for the destruction of the old port and French buildings as it taught tourism courses, Japanese aid (JICA) built a new wall that paved over the walls of the inner royal city, the Chinese ironically destroyed the old French courthouse buildings and the old French era local council buildings for office buildings for the 'Fatherland Front' and for a 'Cultural Center', while the members of ASEM, a group of Asian countries, destroyed the last surviving Eiffel French era bridge. This was all despite their having signed on to multiple treaties and protocols for heritage protection. This policy of 'development' seemed to clearly fit Berman's thesis of destroying all identities and nature in order to disorient, uproot and destroy all local identity in ways that would pave the way for industrialization.

Was 'modernist' industrialization the goal and a unique force? Or, was this just a case of classic imperialism, now in the form of a gang attack by multiple countries, to eliminate local identity and open the door to foreign control?

Counterargument and Critique: While the contemporary period is an age of new technologies of immense power and scale, with certain groups who have a religious zeal for those technologies and a belief in them, the destructiveness of modern times seems largely limited to destruction of non-technological cultures to absorb them and their resources, it seems to be just a contemporary form of imperialism and high population growth and change as a result of modern technologies. This is a recurring phenomenon in history and the present period is not unique. Indeed, much of the destruction that occurs is for the benefit of an elite 'colonial' group, externally and internally, without an effort at creating the kind of culture that actually would drive the permanent technological change that would be expected in a culture that truly worshipped technology.

If techno-fetishism were the driving force of contemporary industrial culture, the culture would promote it directly in other areas. One would expect to see high investment everywhere in education rather than in luxury or recreation consumption items, so as to promote technological innovation, along with a constant focus on meritocracy and measurements to assure the transfer of resources on the basis of technological innovation. There would be a strong focus on rule of law and on scientific literacy. Though some of this is visible in terms of rights for women and minorities and universal education, there is still very high technological illiteracy in 'developed' countries, let alone in the 'developing' world.

Although 'development' tends to promote a 'middle class' of technical professionals or 'technocrats', recent decades have seen the concentration of wealth and of political power in ways that undermine the development of such a technocratic elite and reinforce class differences. The driving force seems to be to create a class of poorly educated consumers manipulated by institutional elites. The Third world countries do not become modern in the Faustian way, unless they are relieved of their needs to invest in militaries (e.g., Japan and Germany). Most others are kept dependent and do not invest 
in education and technology but in weapons and comforts. 'Development' agencies appear to enforce approaches that assure this rather than those that follow European patterns of savings, investment and taxation. The goal appears to be to transfer moneys to government officials to purchase their loyalty so as to keep access to raw materials and cheap labor, rather than to welcome innovation and competition (Lempert 2015).

What is described as planned obsolescence may just be an artifact of scale and material as well as population growth. Part of the continued building and rebuilding in the contemporary world is a result of growing populations on fixed areas of land. Technology allows populations to increase now as in the past and that requires new forms of construction that are higher and in some ways actually more durable, for these higher populations. That is something that also happened in the past as urban areas were constantly rebuilt for larger populations and agricultural areas became urban. Perhaps, the Romans, Greeks, and Egyptians had monuments built to last forever and sought to preserve certain wonders of the world while destroying the other cultures around them. On the other hand, Western cemetery monuments are also largely still in place. The Asians are tearing up tombs and turning towards cremation only to save space, since they also seek to maintain certain monuments.

The scale of modern urban structures makes stone impossible and is what may seem to make modern structures less permanent, but that may be only an artifact of engineering realities. Only steel has the strength and flexibility for the size required, and the growth of population is too rapid for stronger materials other than cement/concrete. Skyscrapers of stone and brick only go so high.

The idea that contemporary technology has somehow altered consciousness in a way that has never been experienced before and that has completely changed the concept of self, humanity and relationship to nature that has never been experienced before, can also be debunked. The ideas that electricity is the symbol of the anthropocene in that it recreated the world by eliminating circadian rhythms and night; that rapid transit erased the concept of physical distance and separation; and that global communications also changed the sense of information and relationships (Banerjee 2012) are true only in the scale of the transformations. The phenomenon is not new at all. Oil and oil lamps were widespread in ancient Greece and similarly changed views of day and night when they were invented. The Romans paved roads and had wide contacts by sea and land into Asia and Africa, with the center of the empire already a mix of peoples and styles. All of these changes were a matter of degrees over time.

Counter-examples: There are attempts today at permanence as well as examples of early cultures that had concepts of impermanence, suggesting both that 'technofetishism' is not unique today and that it may not even be the driving force of industrial culture today.

The author of this article conducted ethnographic field work in the Soviet Union in 1989-90 (in Leningrad, Russia) and noted that their approach to industrialization, while seeking rapid promotion of heavy industry, was based not on a techno-fetish, but on heavy production and order fetish, under bureaucratic control, with the goal of regularity rather than constant technological change (Lempert 1995). It seemed that the envi- 
ronment of the sub-Arctic itself set limits on the uses of technology. There was certainly a drive for better weapons, but private homes and private cars were only of limited use for travel to country homes ('dachas') in summer months and not for winter use when technologies of mass transit were more appropriate. While population growth led to creation of housing blocks outside of the city centers, the centers were not destroyed and rebuilt, nor there was a demand for continual new technologies. Perhaps there was some fetishism, particularly among government officials, for heavy industry, but it seemed to be more for the centralization and order and control more than for the technology, itself.

Meanwhile, the idea of destroying creations to build anew is not something unique to contemporary technology. In Hinduism, one of the oldest religions of an ancient technological civilization of India, a central concept that continues in other Indian religions like Buddhism, is that of a cycle of death and rebirth. The deity, Siva, is the creator and the destroyer. The central ideology of that early technological society was one of impermanence, where objects were built, destroyed and rebuilt.

\section{Analysis of the Deep Structure Argument of 'Capitalism' or 'Corporatism'}

The argument: One of the early social theories proposed to explain industrial society as not based on the worship of technology but driven by industrial organizations in the search for profits as a return on investments in technology, in the form of 'capital' (Marx and Engels 1906. More than a century after Marx and Engels sought to define the driving force of contemporary industrial societies as the search for profits through markets for the products of this 'capital' (a refining of this argument by Hobson [1902]), many still blame the ills of modern society on this supposed driving force of 'capitalism', represented by the form of the modern corporate enterprise, and supported by corrupted governments on their behalf through the politics of 'corporatism'. According to this theory, there is no ethos of worship of technology or of consumption of the products of technology, but simply the worship of 'capital' itself and the transfer of power and control to the organizations and people who have and manipulate 'capital' with a worship of 'capital'.

Counterargument and Critique: History and social science research already seem to have proven that there are specific aspects of the 'profit motive' (production and storage) that are inherent in human (and animal) nature. All animals seek to find resources to boost the survival of their own genes and only cooperate when it promotes survival (Axelrod 1984). Indeed, removal of 'corporate capital' as the organizing principle for technological innovation and advancement does not somehow change the destructiveness of productive organizations. Modern industry and the technicians who work for it still work in much the same way when they are 'owned' by the public.

As Marx, himself, originally argued, 'state socialist' (or 'monopoly capital') productive structures are largely inter-convertible forms of political control (what some refer to today as the convertibility between corporatist 'white fascism' and state socialist 'red fascism'). Contemporary political economists have long recognized that no economies are absolute forms of either private control (of capital) without regulation or 
full state control, and that all economies are essentially 'mixed' systems of public, government incentives and regulation, and private incentives (Lindblom 1977), with relatively similar hierarchies that are inter-convertible (Lempert 1995). While modern '-isms' are used to label economies that are trading partners as friends, or competitors as foes, it is mostly the productive technology itself that determines the political power hierarchy, labor hierarchy and mix of incentives for production (Granick 1960; Lempert 2016b).

The overseas activities of productive organizations may simply be a type of organization of colonial extraction of resources and promotion of trade that is certainly not unique to modern times. What is described today as neo-colonialism is a copy of something that came before (Frank, Cochcraft and Johnson 1972; Wallerstein 1979; Gallagher and Robinson 1953) that was based in states, but there are many examples in the ancient world of traders, producers and piracy that were semi-autonomous of national ties.

\section{Analysis of the Deep Structure of Consumption and Growth Ideology}

The argument: A variant of the belief in 'capitalism' as the driving force of industrial society, and a view that is in some ways opposite to the argument that modern society fetishes technology, is that modern industrialization is, instead, driven by consumption and addiction to the novelty of consumer goods in a kind of gluttony, referred to as a 'consumption fetish' (Hamilton 2003; Schor 2004; Bauman 2007). In popular culture, this driving force is identified in the words of the gangster, Johnny Rocco, Edward G. Robinson's character in the film "Key Largo" (1948) whose understanding of his own motives was that they were simply that of insatiability. 'That's what I want, MORE. I never get enough.' Contemporary economics has enshrined this motive as that of all society, everywhere, in its fabrication of the 'economic man' as the embodiment of the deep structure of consumerism.

Often linked with the idea of 'consumption' as the driving force are those of 'growth' and 'production'. The measures that countries and international organizations routinely use for the measures of an economy are not the creation of 'wealth' and value of assets, the way the health of businesses are measured by standard accounting practices, or of actual consumption, but of 'production' measured as 'Gross Domestic Product' (GDP). As many economists note, GDP claims to be a measure of 'production', it is not a measure of technical advance and productivity or of wealth. It is really a measure of consumption. The sale of a country's assets and the depletion of assets as they are transformed into consumer products, as well as the 'consumption' of people and their labor is what is being measured. It is a direct measure of sales, which equates to consumption (Horngren et al. 2005; Daly and Cobb 1989).

Counterargument and Critique: If 'consumption' were really the driving principle of modern industrial cultures, one would expect there to be constant efforts to promote consumption at all levels, including high levels of redistributive taxation that would increase consumption among the poor, but this is not the case. Rather than promote consumption, it appears that consumption may actually be a marker for the creation of 
class differences and for the promotion of debt that is used as a form of control. Neither of these approaches is unique to modern cultures. Indeed, although economists seem to believe that the insatiable consumer, 'economic man', represents the driving force of our culture (and of all contemporary and ancient societies), that view and the profession are already under attack for creating a propagandistic view to promote a self-interested corporate agenda for the benefit of its sponsors (Lempert 2018c).

While the Nobel Prize winning economist, Milton Friedman, announced some half a century ago that, 'We are all Keynesians now' (Friedman 1965), meaning that all modern societies and their economists supported constant promotion of consumption, including intervention by government to do so (Keynes 1936), the 'now' may have only been between the 1930s and 1960s. Contemporary economic polices do not seek to transfer money to those who would consume most, or to invest in productive investments that would boost consumption and production (i.e., education and welfare rather than military and prisons, which work to promote fear and control rather than stimulate consumption). Tax cut policies do not promote consumption or investment but largely transfer wealth to the rich (Reaganomics). Moreover, current studies of the relationships between center and periphery, both within countries and in neo-colonial relations, suggest that the goal of assimilation and control is not to promote consumption, though there is a goal of manipulating consumption patterns so that they are uniform and dependent on global corporate production. The 'shock therapy' and 'shock doctrine' policies that international financial institutions impose seek to entrench low wage economies under global control, with restraints on government spending and distribution that would stimulate local consumption (Klein 2007).

The idea of promoting consumption itself is a feature of all empires, both to maintain social control in class systems and also to create diversions. The Roman concept of 'panem et circenses' ('bread and circuses') reflects the introduction of grain distribution and diversions for the poor that date back to 140 B.C.E. (Juvenal, 100 B.C.E. [1918]).

Meanwhile, even while industrializing, certain cultures still maintain relatively low levels of per capita income and consumption because they prefer to produce more children at a younger age (e.g., the Vietnamese). The cultural logic does include consumption of all existing resources and promotion of expansion (and people to serve in the militaries to promote that expansion), but this is a cultural pattern that has been part of the culture for centuries. It is not new to contemporary industrialization.

Recently, attention of social observers has focused not on 'consumption' itself but on the result of consumption, which may point to a deeper logic. Most Americans, for example, find themselves in debt. The usual explanation is that there is overspending and too little planning and savings, but examination of the holders of the debt shows that much of it is in the hands of young people with student loans, families with low incomes unable to pay off mortgages or hospital bills, and others on fixed incomes. Some economies provide free education and social insurance and their savings are higher and debts are lower. In other words, the driving force here may actually be the creation of debt by banks. Nobel Prize winning economist Joseph Stiglitz has said that 
the goal of the World Bank and international institutions is, in fact, to create debt as a way of increasing political control (Stiglitz 2002).

The inducement of debt to create and maintain social stratification and control has a long history, starting with the European debtors' prisons and indentured servitude. Slavery was largely replaced by forms of debt service, also allowing for the taking of lands of indebted peasants. If this is the driving principle, it has a long history and is not unique to contemporary industrialization.

State socialist systems did not use the debt approach to exploit labor for industrialization but they did and do use moral persuasion backed by military force to reinforce the 'debt' that citizens owed the government for its winning them 'independence' and protecting them against 'foreign enemies'. This kind of 'Party loyalty' to establish allegiance to elites is used in democracies, as well. In the U.S. the Democratic Party elites seek allegiance of its members as acknowledgment of a thanks for past New Deal programs and civil rights, even though its recent positions have largely disavowed this form of social progress and protection that it supported in the past.

In the history of the French colonial 'civilizing mission' and British and American imperialism, the common logic was to induce addictions among peoples of the colonies and then to use this addiction as both a source of profit as well as a means of weakening the locals for control. This suggests that debt may just be the contemporary form of creating a consumption addiction that reinforces obligations and control. For the French, the goal was to introduce alcohol (and beer) and to use this as the central tax. The British chose to induce opium addiction in its colonies (McCoy 1972). The Americans used the trade in rum on Native Americans, with the legacies of alcoholism still visible today.

Feudal systems also worked on the basis of debt, with land 'rented' and serfs paying the tax on production on the land and with tithes to the church as a kind of debt obligation, but these were also a set of ties for kinship, military protection, and insurance and not just 'debt'.

\section{Analysis of the Deep Structure of Militarism}

The argument: While militaries date back at least three thousand years, to early empires, some observers claim that the driving force of contemporary industrialization is that of a new form of military financing and incentives that link militaries to specific corporate benefits and forms. The general form of this argument, dating back at least to Lenin's formulation of imperialism (1926), is that military conflicts today are not driven by ethnic and national competition for resources but by independent corporations seeking financial advantage (such as control of Middle East Oil) and essentially engaging in alliances with military technology to promote joint interests of profit and control, with militaries themselves sharing in profits and acting as corporations. In this formulation, industrialism is driven by militaries, military corporations, and other corporations working together to establish control and profit for a small group of elites.

The more modern statement of such a cultural logic is that it is driven by a specific group of elites that form a 'power elite' of military, economic and political interests 
(Mills 1956) or a 'military industrial complex' (Melman 1974) and that this is the deep structure (Lempert 2017b). In this system, it does not really matter what is produced or for whom. The products may be opium or alcohol to addict natives (as they were used in Asia and the Americas) (McCoy 1972), slaves, or weapons. There is no logic of social benefit or need, only destructiveness and control, including elimination of all local identities and creation of vulnerability and fear. This is also seen as the root of modern totalitarianism, dominated by military and police. Part of the argument is that technological change is largely driven by military technologies of destruction and control, with military rather than public investments as the real source and location of industrialization.

Counterargument and Critique: The idea of militarism as the source of industrialization, independent of nationalism, may now be part of the underpinnings of globalization and the creation of an international financial, political, and military-security elite, but it does not describe how the system arrived at where it is even just a few decades ago (Howe 2002) and there is no consistent military industrial model in industrialized countries. In fact, after being demilitarized following World War II, the fastest growing economies who have been able to widely expand their interests were (West) Germany and Japan. Though Japan was largely a one-party corporatist state for much of this period, (West) Germany was not. Other countries that had small militaries and rapid technological change, like Sweden, have had military production (for the U.S.) but no strong acting military. Meanwhile, in countries recently industrializing like Vietnam, that do have major militaries with their own commercial interests interlinked with major corporate power, governments still rely on (racial) nationalism to maintain their legitimacy and secure their control while promoting the continuation of cultural destruction and 'sacrifices' that would otherwise trigger violent opposition. Further, many systems that are military dictatorships are not promoting technological change but are consuming and selling off resources and essentially maintaining feudal economies (such as Kazakhstan and North Korea).

Feudal systems were also driven by military, so it is hard to see the contemporary examples as something unique. The peasants were under obligations to the lord in the castle to provide military protection as well as some redistribution (storage in the castle and some redistribution by the church), though the ties were a mix of economic protection and kinship relations.

Overall, militaries seem largely independent of technological changes. 'Security' concerns may drive technology, but the military as an institution does not necessarily seem to drive it. As long as control is maintained, the militaries do not seem to care about industrializing or innovating. They seem to do so only when they need technologies to maintain their power.

\section{Analysis of the Deep Structure of Bureaucracy: Technological Feudalism}

The argument: What all of the four explanations, above, may have in common but not explicitly state, is that what they are identifying as the driving force of modern industrial cultures is actually the authority of specific and novel forms of institutions, for eco- 
nomic productivity, distribution/consumption, and military control. The driving force of modern cultures that represent something new may be 'bureaucracy'; the institutional and organizational form of the new industrial or administrative state. These administrative structural forms are created to organize large numbers of peoples and specializations in ways not previously needed or envisioned. Their incentive systems and oversight largely result in these institutions running themselves and exerting control over the cultures in which they arise, in ways that are often seen as running amok (Galbraith 1967; Kafka 1922; Weber 1947; Durkheim 1964 [1893]; Duncan 2014).

In criticizing the Soviet Union's economic and military bureaucracies, the 'renegade' Karl Kautsky was one of the first to note that no matter what the claim as to political control, bureaucracies like those of the Soviet Union, as a form of bureaucratic military imperialism, have come to be the defining principle of contemporary industrialization in a dangerous way (Kautsky 1914). Social observers throughout the $20^{\text {th }}$ century, in literary and in popular intellectual work, have largely identified institutions as shaping people and falling outside of control (Goodman 1965; Whyte 1956). These observers have directly or implicitly argued that institutions have become the driving force of the cultures and are maintaining themselves and their directives in dangerous ways that are difficult to influence once they began to operate.

Counterargument: Although there are many theories of public administration and institutional control, all essentially recognize bureaucracy as a modern phenomenon despite some historical examples such as imperial militaries and specific divisions of labor in all societies. The idea that bureaucracy is the unique phenomenon of contemporary societies and not just an intensification of earlier phenomena is a question I partly leave open as a social science question that itself requires social science; comparative study. While ancient Greek plays include satirical references to the bureaucrats and professions of the time as part of the divisions of labor and stereotypical behaviors, and while there were always classes or castes filling specific roles, it isn't easy to analogize them to the workings of modern bureaucracy. While political science studies 'institutional interests' and while sociologists may study 'class interests' in interpreting historical examples, along with psychologists who study individual motivations within bureaucratic systems, contemporary organizational forms of bureaucracies do not really have historical correlatives that make it easy for comparative study.

There is no clear driving principle associated with bureaucracies other than the survival of the institutions, themselves, once they are formed. If they are militaries or companies selling addictive substances or enterprises extracting resources and causing environmental damage to save costs, they all exist for those very purposes.

What may be comparable is the existence of empire, its dependency on certain institutions, and the ideology that protects those institutions, but the challenges of modern bureaucracy and their ability to shape opinion and protect themselves, may be a unique driving force. 


\section{Discussion and Predictions using Social Science Analysis}

Whether or not the above analysis of the deep structure of contemporary industrial cultures is correct, social science analysis suggests that the paths of all five of the driving forces that social observers have identified in industrial societies today all appear to lead to collapse unless some unidentified corrective mechanisms exists to divert them. One of the paradoxes of contemporary society is that while seeming to promote industrialization and science, contemporary culture has essentially dismantled social science and severely handicapped its ability to predict and create technologies to correct the paths that seem to be leading towards collapse. While scholars today claim that there is no valid way to study and predict the paths contemporary societies through social science, the forces that they suggest drive them are also forces that will destroy them and the lack of use of applied social science to seeking solutions leaves only an ineffective reliance on 'faith'.

Sustainability: Taken in turn, none of the five driving forces identified above seem to actually support a sustainable industrial culture:

- The idea of 'techno-fetishism' has come with tremendous social costs of future shock and dislocation while also inducing a backlash of nature (climate change) because of the inability to incorporate either the realities of the natural world or inherent human needs for affiliation, stability, and beauty. The destructiveness of technological change has led both to large social costs and to consumption of comforts that actually outweigh the ability of technological change to produce them (Nguyen 2008).

- Corporatism/capitalism is not sustainable as a driving force because the drive for monopolization and control ultimately stifles social mobility and innovation and also drives up costs for social control. These systems collapse unless they are replaced with strong democratic regulatory controls.

- Consumption fetishism is also unsustainable as a driving force because the idea of human creation of the environment without limits is a myth. Humans cannot consume nature without replenishing it and living with it, which requires limiting consumption and redefining it, rather than feeding it.

- Militarism as a driving force is also unsustainable because it destroys resources and societies and destabilizes while suppressing innovation.

- Uncontrolled institutional bureaucracies, seeking benefits through specific functions that exploit peoples and the environment, ultimately destroy what they are designed to promote. While this author has designed a number of potential oversight mechanisms for public control of all kinds of bureaucracies, public and private, the modern paradox is that bureaucracies themselves prevent discussion of restraints. Institutional logic and its teachings are to widen discretion and minimize control in every way possible.

Failure of Social Science: Rather than strengthen social sciences to address contemporary questions of industrial society, much of the current trend has been to retreat and reinvent social science as either advocacy for certain existing institutions and beliefs (in line with the logic of bureaucracy and institutions protecting themselves, de- 
scribed above) or to serve as an avenue for opinion without science, under the label today of 'post-modernism'.

While full discussion of this is outside of the scope of this piece, beyond the criticisms noted and cited above, this phenomenon was foreseen and predicted decades ago by those who were doing social science and whose work is now suppressed (Harris 1979). As Berman predicted, some 35 years ago, 'social scientists, embarrassed by critical attacks on their techno-pastoral models, have fled from the task of building a model that might be truer to modern life' (Berman 1982: 33). What has emerged today in social science is largely narcissism or journalism with no vision and presentation of local rather than objective perspectives, without scientific method of testing. Some of its heroes, like Michel Foucault, present society as a singularity of institutions and ideology that essentially strait jackets any kind of analysis or study (Berman 1982: 33-34).

\section{Conclusion}

At a time when both better predictions and technical applications for solutions are necessary for human survival, the religious and ideological decision to deride and prevent comparative study of contemporary societies with those of the past limits the ability to predict pathways of change and to engineer social solutions. [A longer version of the conclusion is presented in the on-line version of this article.]

\section{REFERENCES}

Axelrod, R. 1984. The Evolution of Cooperation, New York: Basic Books.

Bakunin, M. A. 1992. The Basic Bakunin: Writings 1869-1871. E. Robert M. Cutler. New York: Prometheus Books.

Banerjee, A. 2012. We Modern People: Science Fiction and the Making of Russian Modernity. Middletown, CT: Wesleyan University Press.

Bauman, Z. 2007. Consuming Life. Cambridge, MA: Polity Press.

Baumeister, R. F. 1995. The Psychology of Irrationality: Why People Make Foolish. SelfDefeating Choices. Case Western Reserve University, unpublished manuscript.

Bell, D. 1972. The Post Industrial Society: the Evolution of an Idea. Survey 17(2): 102-168.

Berman, M. 1982. All that is Solid Melts into Air: The Experience of Modernity. New York: Simon and Schuster.

Daly, H., \& Cobb, J. 1989. For the Common Good. Boston: Beacon Press.

Dickens, Ch. 1859. A Tale of Two Cities. London: Chapman and Hall.

Duncan, B. 2012. Post-Cold War Anthropology as Blog. Journal of Developing Societies 29(1).

Duncan, B. 2014. Convergence Theory Revisited: Kafkaesque Global Bureaucracies of Our Times: With an Example of a Tool for Measuring Whether Approaches to Accountability are Real or Sham. Social Evolution and History 13(1): 67-98. URL: http://www.sociostudies.org/journal/articles/242735/

Durkheim, E. 1897 [1951]. Suicide. New York: The Free Press.

Durkheim, E. 1964 [1893]. The Division of Labor in Society: Study of the Organization of Higher Societies. Glencoe, IL: The Free Press. 
Frank, A. G., Cochroft, J. D., and Johnson, D. L. 1972. Dependence and Underdevelopment: Latin America's Political Economy. Garden City, New York: Anchor Books.

Freire, P. 1970. Pedagogy of the Oppressed. New York: Seabury Press.

Friedman, M. 1965. We Are All Keynesians Now. Time. December 31.

Galbraith, J. K. 1967. The New Industrial State. New York: Houghton Mifflin.

Gallagher, J., and Robinson, R. 1953. The Imperialism of Free Trade. The Economic History Review, 6: 1-15.

Goethe, J. W. 1961 [1832]. Faust. (transl. Walter Kaufmann). New York: Doubleday and Company.

Goodman, P. 1965. People or Personnel. New York: Vintage.

Granick, D. 1960. The Red Executive. New York: Anchor Books.

Hamilton, C. 2003. Growth Fetish. Sydney: Allen \& Unwin.

Harris, M. 1979. Cultural Materialism: The Struggle for a Science of Culture. New York: Random House.

Hobson, J. 1902. Imperialism: A Study. London: Allen and Unwin.

Horngren, Ch. T., Harrison, W. T., Bamber, L. S., Willis, B., \& Jones, B. 2005. Accounting. Pearson Education.

Howe, S. 2002. Empire: A Very Short Introduction. Oxford, England: Oxford University Press.

Huntington, S. 1968. Political Order in Changing Societies. New Haven: Yale University Press.

Juvenal (100 B.C.E. [1918]), Satire, 10: 77-81.

Kautsky, K. 1914. Ultra Imperialism. Die Neue Zeit, September. URL: https://www.marxists. org/archive/kautsky/1914/09/ultra-imp.htm.

Keynes, J. M. 1936. The General Theory of Employment, Interest and Money. London: Palgrave Macmillan.

Klein, N. 2007. The Shock Doctrine: The Rise of Disaster Capitalism. New York: MacMillan.

Kafka, F. 1922. The Castle (Das Schloß). Munich: Kurt Wolff Verlag.

Lempert, D. 1987. A Demographic Economic Explanation of Political Stability: Mauritius as a Micro-cosm, Eastern Africa Economic Review 3(1).

Lempert, D. 1995. Daily Life in a Crumbling Empire: The Absorption of Russia into the World Economy. 2 vols. New York: Columbia University Press, Eastern European Monograph Series.

Lempert, D. 2012. The Social Science of Empire. (Review Essay using four books of 'The American Empire Project'), Journal of Developing Societies 28(4): 441-68.

Lempert, D. 2014a. Classifying Cultures by Their Relations in Groups: Drawing from Models in Psychology and Ecology. Social Evolution and History 13(1): 99-134. URL: http://www.sociostudies.org/journal/articles/242737/.

Lempert, D. 2014b. What is Development? What is Progress?: Contributions of Utopian Thinking. Journal of Developing Societies 30(2): 223-41. 
Lempert, D. 2015. A Quick Indicator of Effectiveness of 'Capacity Building' Initiatives of NGOs and International Organizations: A Solution for Accountability. European Journal of Government and Economics, 4(2): 155-196. URL: http://www.ejge.org/index. php/ejge/article/view/63/59.

Lempert, D. 2016a. The Myth of Social Progress, Revisited. Human Figurations: Long Term Perspectives, 5(1). URL: http://quod.lib.umich.edu/h/humfig/11217607.0005.107/ --myth-of-social-progress-revisited?rgn=main;view=fulltext.

Lempert, D. 2016b. Predicting Political Systems Using Economic, Environmental and Relational Variables. Social Evolution and History 15(2): 164-194, September. Longer Version on the web: https://www.sociostudies.org/journal/articles/588599/

Lempert, D. 2017a. The Logic of Cultural Suicide and Application to Contemporary Global Strategies: Drawing from Models in Psychology and Biology. Journal of Globalization Studies 8(1); 120-139. URL: https://www.sociostudies.org/journal/articles/939397/

Lempert, D. 2017b. The Deep Structure of U.S. Political and Legal Culture: An Anthropological View of 'Deep Politics'. Peace Studies Journal, 10(1): 20-56. URL: http://peaceconsortium.org/peace-studies-journal/archives/psj-vol-10-issue-1.

Lempert, D. 2018a. The Psychology of Cultural Suicide and Cultural Change. Journal of Globalization Studies 9(1). URL: https://www.sociostudies.org/journal/articles/1643760/.

Lempert, D. 2018b. Returning Discipline to the Discipline: A Model Procedure for Reviews in Anthropology, Other Social Sciences, and Related Disciplines. Catalyst: A Social Justice Forum, 8(1): 301-326. URL: http://trace.tennessee.edu/catalyst/vol8/iss1/10.

Lempert, D. 2018c. Is Economics in Violation of International Law?: Remaking Economics as a Social Science. Catalyst: A Social Justice Forum 7(2): 99-260. URL: http://trace. tennessee.edu/catalyst/vol8/iss1/6.

Lempert, D. 2018d. Futurology Needs to Focus on Measurable Variables, Causality and Social Structural Models and Learn from Past Mistakes: A Response to 'A History of Possible Futures: Multipath Forecasting of Social Breakdown, Recovery, and Resilience'. Cliodynamics: The Journal of Quantitative History and Cultural Evolution 9(2): 240-261. URL: https://escholarship.org/uc/item/1247c4xr.

Lempert, D., Nguyen Nhu Hue. 2011. The Global Prisoners’ Dilemma of Unsustainability: Why Sustainable Development Cannot Be Achieved Without Resource Security and Eliminating the Legacies of Colonialism. Sustainability: Science, Practice and Policy, 7(1). URL: http://sspp.proquest.com/archives/vol7iss1/1006-031.lempert.html and http://www.pelicanweb.org/solisustv07n10page4.html.

Lenin, V. I. 1926. Imperialism, The State and Revolution. New York: Vanguard Press.

Lindblom, Ch. 1977. Politics and Markets: The World's Politico-Economic Systems. New York: Basic Books.

Marx, K., Engels F. 1906 [1867]. Capital: A Critique of Political Economy New York: Modern Library.

McCoy, A. 1972. The Politics of Heroin in Southeast Asia. Singapore: Harper \& Row.

Melman, S. 1974. The Permanent War Economy: American Capitalism in Decline. New York: Simon and Schuster.

Mills, C. W. 1956. The Power Elite. London: Oxford University Press. 
Nguyen, Hue Nhu 2008. Toxic Omissions: and Cancerous Growths: Addressing the Unexamined Assumption of Sustainable Consumption in Technologically Innovative Societies. Masters Thesis, Lund, Sweden: IIIEE Lund University, IIIEE Theses 2008: XX. URL: http://www.etd.ceu.hu/2008/nguyen_hue.pdf.

Nietzsche, F. 1873. The Use and Abuse of History.

Pierson, M. H. 2007. The Place You Love is Gone: Progress Hits Home. New York: W.W. Norton and Company.

Rousseau, E. 1761. Julie, ou la Nouvelle Heloise. in Ouvres Complete, Volume II.

Schor, J. 2004. Born to Buy. New York: Scribner and Sons.

Sly, P. 2018. The Nonsense and Non-Science of Political Science: A Politically Incorrect View of "Poly-T(r)icks". Catalyst: A Social Justice Forum 8 (1): 268-300. URL: http://race.tennessee.edu/catalyst/vol8/iss1/9.

Stiglitz, J. 2002. Globalization and its Discontents. New York: W.W. Norton \& Company.

Toffler, A. 1970. Future Shock. New York: Random House.

Wallerstein, I. 1979. An Historical Perspective: The Emergence of the New Economic Order. The Capitalist World Economy. New York: Cambridge U. Press.

Weber, M. 1947. Theory of Social and Economic Organization. (A. M. Henderson and Talcott Parsons, transl.) New York: Free Press.

Whyte, W. 1956. The Organization Man. New York: Doubleday. 